\title{
Economic Planning and Real Sector Development in Nigeria
}

\author{
Udeorah Sylvester Alor $\mathbf{F}^{\mathbf{1}^{*}}$, Nchom Humphrey ${ }^{2}$, Yusuf Lateef Olarotimi ${ }^{3}$ \\ ${ }^{l}$ Department of Economics, Faculty of Social Sciences University of Port Harcourt, Nigeria \\ ${ }^{2,3}$ Institute of International Trade and Development, University of Port Harcourt
}

\author{
*Corresponding Author: Udeorah Sylvester Alor F, Department of Economics, Faculty of Social Sciences \\ University of Port Harcourt, Nigeria
}

\begin{abstract}
One of the main purpose of planning in both advanced and underdeveloped nations of the world is to achieve sustained economic development. This can be done through importation of capital from foreign nations and localized force saving to support the level of industrial development in the real sectors of the economy. The fundamental focus of this paper is to examine economic planning and real sector in Nigeria. The paper used library science method and collected data purely from secondary materials. The paper found that amongst the challenges of the real sectors development is poor government policies and monoculture nature of the Nigerian economy. These consequently resulted into not achieving macroeconomic objectives such as increase in output growth in all the sectors as expected. The paper therefore suggested articulated development plan, improved governance and service delivery. Governments should create an enabling environment through her planning for private driven economy to thrive through realistic power and energy programmes and reforms, functional institutions. This will encourage local industries and foreign direct investments into the real sector of the economy thereby increasing the levels of economic development in the economy.
\end{abstract}

Keywords: Development, Economic, Market imperfection, Planning, Real Sector.

\section{INTRODUCTION}

Economic planning has been the foundation of attaining development goals in many successful developing nations. Thus, economic planning is a mechanism for the allocation of resources between and within organizations which is held in contrast to the market mechanism. As an allocation mechanism for socialism, economic planning replaces factor markets with a direct allocation of resources within a single or interconnected group of socially owned organizations. At the heart of such planning is effective coordination and integration of development policies, whether fiscal, monetary or social, across government. However, in spite good intents that always strengthen development strategies, the development plans of many emerging economies is expected to trigger growth in the real sectors but either fail outright or produce insufficient average returns (Musila, 2007; Geda,Karingi, Ndungu, Van Schaaijk, Wasala\&Obere, 2001).

Meanwhile, according to Ewubare and Obayori (2015), the real sectors are sectors responsible for the production of goods and services via the utilization of raw materials and other factors of production such as labour force, land and capital. Moreover, the real sectors entails those areas of activities in the agricultural and industrial sectors that result in the production of traded and non-traded goods and services. Thus, the citizenry of a nation has to work hard to produce goods and services to be able to compete favourably with the rest of the world. The ability to compete with other nations is a key element to survival as a nation. Hence, there is need for sustained increase in production in all the sectors of any economy (Udabah, 2010).

It is pertinent to make clear that the real sector of the Nigerian economy mainly consist of production in both the agricultural and the industrial sectors. In the agricultural sector, production is categorized into crops, staples, livestock, fishery, forestry and other produce (CBN, 2018). On the other hand, production in the industrial sector is split into manufacturing, mining, electricity, among others.

The requirement to improve the real sector output cannot be over-emphasized given predominantly the less promising economic situations that face most developing nations nowadays, manifested in high poverty rate and unstable performance of major macroeconomic variables. This has the effect of 
weakening output growth via procurement of factor inputs as expenditure on off-shore inputs, which make-up the bulk of total inputs (CBN, 2013). Thus, to trigger and sustain growth momentum, enhancing real sector performance is absolutely critical. Therefore, Nigeria, like other developing countries of the world views high industrial and agricultural production as vital for rapid economic growth and development.

\section{Conceptual Review}

\subsection{Economic Planning}

According to the Marxists, planning involves controller of surplus product (profit) by the associated producers in a democratic manner. Economic planning is therefore an instrument for the distribution of resources within organizations which is held in divergence to the market instrument. As adistributionmachinery for socialism, economic planning substitutes factor markets with a direct provision of resources within interrelated collection of socially owned establishments (Mandel, 1986).Economic planning can be differentiate into centralized planning and decentralized planning. In a centrally planned economy, distribution of wealth is determined byall-inclusive plan of production which identifies output demand. This planning may also take the form of directive planning or indicative planning.In contrast, decentralized-planning systems are based on collective decision-making and disaggregated information to centralized systems of planning conducted by practical specialists who use collected data to convey plans of production (Bockman, 2011).

The theoretical postulates for models of decentralized socialist planning started from the thought of Karl Kautsky, Rosa Luxemburg, Nikolai Bukharin and Oskar Lange. The model comprises economic decision-making based on self-governance from the bottom-up (by employees and consumers) without any directing central authority (Friedman, 1957).As such, decentralized planning often appears as a complement to the idea of socialist self-management.

\subsection{Socialist Planning}

The classical idea of socialist economic planning conceived by the Marxists involved an economic system where goods and services were valued, demanded and produced directly for the society usevalue as contrasting to being produced as a by-product of the pursuit of profit by business enterprises. This idea of production for use is a fundamental aspect of a socialist economy. "This involves social control over the distribution of the excess product and in its most extensive theoretical form calculation-in-kind in place of financial calculation". This be at variance from planning within the framework of capitalism which is founded on the planned accumulation of capital in order to either stabilize the business cycle or to maximize profits as opposed to the socialist concept of planned production for use.

In the context of mainstream economics and the field of comparative economic systems, socialist planning is otherwise known as "the Soviet-type command economy", regardless of whether or not this economic system actually constituted a type of socialism or state capitalism or, non-socialist and non-capitalist type of system. In socialist culture, the primary function of the state apparatus varies from one of political rule over people (via the enforcement of laws) into a technical administration of production, distribution and organization; thus the state would become a coordinating economic entity rather than a mechanism of political and class-based control and thereby ceasing to be a state in the traditional sense.

\subsection{Planning Versus Command.}

Command economy is differentiated from a planned economy and economic planning, especially by socialists and Marxists who liken command economies (such as that of the former Soviet Union) to that of a single capitalist firm, organized in a top-down administrative fashion based on bureaucratic organization akin to that of a capitalist corporation.

Economic analysts and public commentators argued that the economy of the previous Soviet Union essentially exemplified an administrative or command economy as opposed to a planned economy since planning did not play an operational role in the distribution of wealth among productive units in the economy since the main distribution apparatus was a system of command-and-control. As a result, the phrase administrative command economy gained currency as a more accurate descriptor of Soviettype economies (Wilhelm, 1985). 


\section{NeEdS For Planning in DEVEloping Countries}

One of the principal ideas of planning in developing countries is to increase the rate of economic development. Considering the words of Professor Gadgil, planning for development implies external direction or regulation of economic activity by the planning authority which in most cases identified as the government. As a matter of fact, LDC's are characterized with low level of savings, low level of income, what is prevalence in such countries is poverty inflicted people. This visions economic circle can only be broken by planned development through capital importation and localized force saving to support the level of industrialization (Boskin, 1982).

Therefore, the rationale and the need for planning arises in such countries to achieve the following;

1. Strengthen the market mechanism: Less developed developing countries are usually characterized by imperfect market mechanism due the fact that the production factor, money and capital markets are not organized properly, thus the price system fails to bring about adjustments between aggregate demand and supply of good and services. Therefore, these bottle neck can be remove through planning using a workable planning model.

2. The necessity of removing poverty and unemployment: The need for reducing income inequalities by raising per-capital income and as well increase employment opportunities will enhance rapid development. A situation where resources are not fully utilized and labour is in abundance thereby creating the problem of providing gainful employment and resulting in absence of sufficient enterprises and initiatives (Keynes, 1936). This required an urgent attention by the planning authority in developing nationsby adopting a planning model that can salvage the situation.

3. The development of agricultural sectors ad industrial sectors: Given the importance of agricultural sector in term of provision of food, rawmaterials and foreign earnings as well as the importance of industrial sector for transforming the raw materials from the agricultural sector to finished goods, there should be a conscious attempt by developing nations planning authority to chart a road map planning model that will develop both the agricultural and industrial sectors which are key to sustainable development.

\section{The REAL SECTOR In Nigeria}

The real sector of the Nigerian economy has perhaps been a catalyst that determine the country's economic transformation over the years. Prominently, the sector has transformed into an emerging industrial mainstay from a hitherto fundamental agrarian economy that can hardly be overlooked.

Nevertheless, the management of the economy never stop to formulate policies and provisioning of financing that will elevate the sector to levels that can make the nation an economic hub and a driver of Africa's economic renaissance. Although, recent records suggest resilient growth, it is incontrovertible to see that currently, most countries that were at the same or even lower stage of development decades ago such as Malaysia have transformed their real sectors beyond mean proportions.

The issues of real sector development in Nigeria remain intricate and reflect a mix of both domestic and international characteristics. The real sector comprises agriculture, industry, building and construction, wholesale and retail and the services sectors, while from the international front, developments in the international oil market and the oil and gas sector are influenced by global financial activities. Thus, the policy environment must be adequately focused towards enhancing the capacity of the private sector to drive real sector activities and hence, achieve desirable levels of growth. There is no gainsaying the fact that the complex interactions of agents and economic activities pose the challenge of clearly understanding the adjustment mechanisms required to attain optimal levels of output. Although not exhaustive, econometric models are helpful tools that could be used in the determination of quantitative signposts to assists policy makers in formulating and implementing sound policies. Formulation and implementation of sound economic policies had made differences between developed, emerging and developing economies, and econometric models have played a part in these differences.

In Nigeria, several models have been developed to assist policy formulation and implementation. Economic model could be dated back to the work of Cater in 1960, who constructed input-output table to aid the formulation and implementation of first National Development Plan. Several other 
models have been developed in order to assist in policy formulation, implementation and analysis (CBN, 2013).

In 2008, the Central Bank of Nigeria developed a macro econometric model of Nigeria to assist the Bank in policy analysis. The model, which was an aggregated model might not be able to capture all the sectoral interplay in the real sector due to the complexity in the workings of the economy. This study, therefore, set out to develop a disaggregated model of the real sector of the Nigerian economy. The model is not to compete with the aggregated macroeconomic model but to complement it and serve as input to the maintenance of the macro model.

\subsection{Sectoral Analysis of the Nigerian Real Sector}

Sectoral analysis of the Nigerian real sectors comprises of both agricultural and industrial contribution to output growth of the economy. According to Ewubare and Obayori (2015), "the share of agriculture to GDP averaged 40.3 per cent during the period 1999-2011". It was 36.7 per cent in 1999; peaked at 43.9 per cent in 200 and stabilized at 40.2 per cent in 2011 . The agricultural sector is expected to play its traditional roles of meeting the food needs of the teeming population, providing the required raw material needs of the industrial sector and providing the envisaged surplus for exports and thereby generating foreign exchange to improve the balance of payments position. The subsistence nature of farming characterized by low adoption of technology, inadequate use of fertilizers and improved seeds accounted for low productivity of the sector. Also, lack of access to adequate funds to invest in the sector had been identified as a major hindrance to improved productivity.

Moreover, the industrial sector consists of manufacturing and mining (including crude petroleum, gas and solid minerals). The manufacturing sector in Nigeria consists of large, medium, small and micro scale enterprises. On attainment of independence, government embarked on transforming the country from its predominantly agrarian nature, into an industrialized economy through various policies and programmes as encapsulated in the development plans. The share of the industrial sector averaged 27.9 per cent during the period of analysis, with its sectoral contribution declining from 35.4 per cent in 1999 to 19.3 per cent in 2011. The decline in the sectoral contribution of the industrial sector to GDP is attributed to various factors including policy inconsistencies and reversals, as well as infrastructural bottlenecks. The share of manufacturing sector averaged 4.0 per cent during the period of analysis. The declining share of the industrial sector, especially manufacturing sector is worrisome as this has exacerbated the unemployment situation in the country (CBN. 2012).

The mining sub-sector is made up of crude petroleum, gas and solid minerals. Solid minerals such as coal and tin used to be the main mining activity and export items for Nigeria prior to the discovery of crude oil. However, this changed following the discovery of petroleum, which has dominated activity in the mining sector, and constituted the major source of government revenue and export earnings. The crude petroleum \& natural gas sector accounted for 23.3 per cent of the share of total GDP during the period under review, which showed a similar declining pattern with the industrial sector falling from 30.8 per cent in 1999 to 14.8 per cent in 2011.

The share of building and construction in the GDP fluctuated around 1.8 per cent during the period of analysis. As a percentage of GDP, the share of wholesale \& retail trade averaged 14.8 per cent during the period 1999-2011. The share of the sector increased during the period of analysis from 13.6 per cent in 1999 to 19.4 per cent in 2011. Similarly, the share of services in GDP averaged 15.5 per cent during the review period, increasing from 12.3 per cent in 1999 to 19.1 per cent in2011.

\section{CONCLUSION}

The real sector of the Nigerian economy has perhaps been a catalyst that determine the country's economic transformation over the years. Prominently, the sector has transformed into an emerging industrial mainstay from a hitherto fundamental agrarian economy that can hardly be overlooked.

Nevertheless, the management of the economy never stop to formulate policies that will elevate the sector to levels that can make the nation an economic hub and a driver of Africa's economic renaissance.

Although, recent records suggest resilient growth, it is incontrovertible to see that currently, most countries that were at the same or even lower stage of development decades ago such as Malaysia have transformed their real sectors beyond mean proportions. The complex interactions of agents and 
economic activities could obscure the understanding of the adjustment mechanisms required to attain optimal levels of output. This study, therefore, developed a disaggregated model of the real sector of the Nigeria economy to complement macroeconomic model earlier built by the CBN.

The performances of the real sector over the years had mirrored the happenings in the economy as a whole. Over the years, oil sector had been the dominant sector in terms of foreign exchange earnings. However, its contribution to GDP had been on the decline since the turn of the millennium. The robust growth rate of GDP during the period 1999-2011 was attributed largely to the development in the non-oil sector. The non-oil (GDP) growth averaged 8.9 per cent in the period $2006-2010$, which grew from 4.4 per cent in 1999 to 8.9 per cent in 2011. The performance of the non-oil sector was driven by the agricultural sub-sector, given its contribution to the GDP, which was over 40 per cent, followed by the services and wholesale and retail trade sectors.

Given the background above, the research therefore suggested articulated development plan, improved governance and service delivery. Governments should create an enabling environment through her planning for private driven economy to thrive through realistic power and energy programmes and reforms, functional institutions. This will encourage local industries and foreign direct investments into the real sector of the economy thereby increasing the levels of economic development in the economy.

\section{REFERENCES}

[1] Bockman, J. (2011). Markets in the name of socialism: The left-wing origins of neoliberalism. Stanford University Press. p. 35. ISBN 978-0-8047-7566-3

[2] Boskin, M. (1982).An empirical evaluation of supply-side economics in supply-sideeconomics in the 1980s, Conference proceedings. Westport: Quorum books:15-25

[3] Central Bank of Nigeria (2012). Annual Report and Statement of Accounts. Abuja, Nigeria

[4] Central Bank of Nigeria (2013). Modelling the real sector of the Nigerian economy. Annual report and statement of accounts. Abuja. Retrieved on 12/08/19 from www.cbn.gov.ng

[5] Central Bank of Nigeria (2018). Annual Report and Statement of Accounts, Various Years.

[6] Ewubare, D.B. \&Obayori, J.B. (2015). The Real Sector Performance and Unemployment Rate in Nigeria. British Journal of Economics, Finance and Management Sciences, 10 (2), 183-194

[7] Friedman, M. (1957). A theory of the consumption function. Princeton University press, Princeton.

[8] Geda, A., Karingi S.N., Ndungu, M., Van Schaaijk, M., Wasala, W. \&Obere, J. (2001). Estimation procedure and estimated results of the KIPPRAtreasury macro model. Working paper WP/05/2001, KIPPRA. Kenya.

[9] Keynes, J.M. (1936). Theory of employment, interest and money. Harcourt, Brace and Company, London.

[10] Mandel, E. (1986). Defense of socialist planning. New Left Review, I (159), 5-37.

[11] Musila, J. L. W. (2007). An econometric model of the Malawian economy. Economic Modelling, 19, 295 330

[12] Udah, E. B. (2010). Industrial development, electricity crisis and economic performance in Nigeria. European Journal of Economics, Finance and Administrative Sciences, 18.

[13] Wilhelm, J. H. (1985). The Soviet Union has an administered, not a planned, economy. Soviet Studies, 37 (1), 118-130

\section{AUTHORS' BIOGRAPHY}

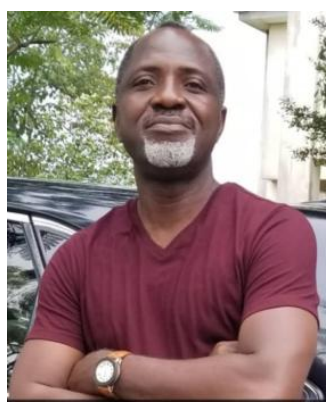

UDEORAH SYLVESTER ALOR F, is a Lecturer and Assistant Director in Institute of International Trade and Development Centre, University of Port Harcourt, Nigeria 


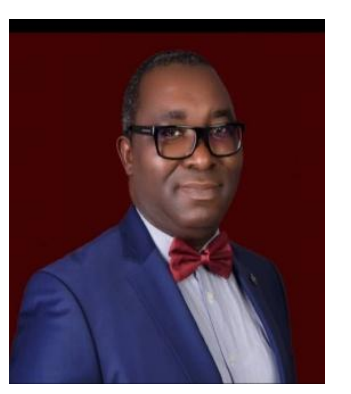

NCHOM HUMPHREY, is a Ph.D student in Institute of International Trade and Development Centre, University of Port Harcourt, Nigeria

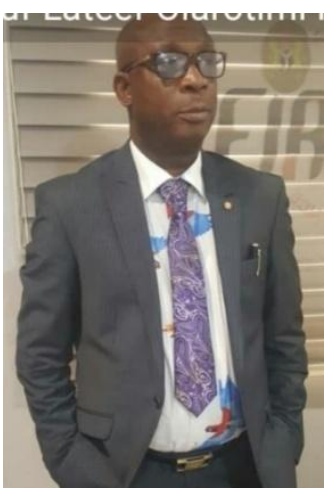

YUSUF LATEEF OLAROTIMI, is a Ph.D student in Institute of International Trade and Development Centre, University of Port Harcourt, Nigeria

Citation: Udeorah Sylvester Alor F, et.al, "Economic Planning and Real Sector Development in Nigeria" International Journal of Managerial Studies and Research (IJMSR), vol 9, no. 3, 2021, pp. 42-47. doi: https://doi.org/10.20431/2349-0349.0903005

Copyright: (c) 2021 Authors. This is an open-access article distributed under the terms of the Creative Commons Attribution License, which permits unrestricted use, distribution, and reproduction in any medium, provided the original author and source are credited. 